\title{
Kosovo west: Environmental assessment of depleted uranium and others radionuclides
}

\author{
F. Banducci, A. Benedetti and A. Cuccuru
}

Centro Interforze Studi Applicazioni Militari, S. Piero a Grado, Pisa, Italy

\begin{abstract}
The poster presents the assessment of the environmental impact of Depleted Uranium (DU) in Kosovo Conflict in 1999. CISAM (Joint Force Centre for Military Studies and Applications) teams performed five environmental check campaigns in Kosovo (first in October 1999, last in May 2001) to study the effect of DU on the environment, collecting samples from 18 sites.

Depleted Uranium and other radio-nuclides concentrations have been measured in environmental matrix; irradiation doses and internal contamination due to re-suspension have been evaluated too.

The results suggest that there is not immediate risk, but scientific uncertainties concern the long term effect of the "lost" DU; other researches are in progress.

The DU results obtained in 18 sites in West Kosovo are reported and summarized, in particular; data are given concerning the site "NATO 98" Radonjick lake.

The results of the campaigns are matched with the conclusive remarks of UNEP and others European organizations.
\end{abstract}

\section{INTRODUCTION}

During the last war in the Balkan area, spring-summer 1999, NATO forces admitted the use in Kosovo of $30 \mathrm{~mm}$ bullets fired by A-10 anti-tank aircraft.

CISAM, Joint Centre of Military Studies \& Application, performed six environmental check campaigns (October 1999, April, August, November 2000, January and May 2001) [1],[2],[3],[4],[5].

In July 2000 , NATO provided the United Nations with a detailed map indicating sites where DU bullets had been used.

The CISAM scientific expert Team, assisted by a Company of the 7th NBC (Nuclear, Biological and Chemical) Regiment "Cremona", during the first and the second mission discovered some places within the area assigned to the Multi National Brigade West (MNBW) where the DU bullets had been used.

The first task of the Team was the collection of samples or data that might be used in assessment of radiation hazard in the KFOR-MNBW troops stay area.

Up to day the Team performed approximately 500 field measurements; the $7^{\text {th }}$ Rgt. NBC surveyed 700 loca-tions and the CISAM Laboratory analysed more than 300 samples.

The aim of all CISAM activities was the protection of the military personnel in the area assigned to the MNBW Command assessing the potential health and environmental impact of DU.

\section{SUMMARISED DEPLETED URANIUM RESULTS}

The survey procedure involved the collection of data on the location suggested from MNBW Command and on the source of the water supplies.

CISAM team used a mobile laboratory equipped with a portable gamma ray spectrometer, an alfa and beta low background counter and several other instruments like Oxford nano ASSIST, Berthold FHT111, Automes 6150/Ad t/1, Victoreen 290 SI and Rotem RAM DA3/GM10.

The background gamma and beta radiation, about $0,10 \mu \mathrm{Gy} / \mathrm{h}$, in the Kosovo-West is due to the bedrock consisting of dolomites rock or basaltic lava like in the site near Radonjick lake. 
The principal monitoring equipment used to discover the DU rounds was the ROTEM DA3 equipped with pancake Geiger GM10; with this instrument it is possible to detect a bullet or a piece of DU laying in the field from a distance of 5 meter.

Gamma spectrometry carried out with nano ASSIST discovered also the presence of caesium-137 in some areas. The laboratory measurements confirmed that the activity concentration of caesium in soil ranged from 5 to $300 \mathrm{~Bq} / \mathrm{kg}$.

In absence of metal scrap, it is possible use the mine detectors to localize the Depleted Uranium bullets to 20-30 cm depth.

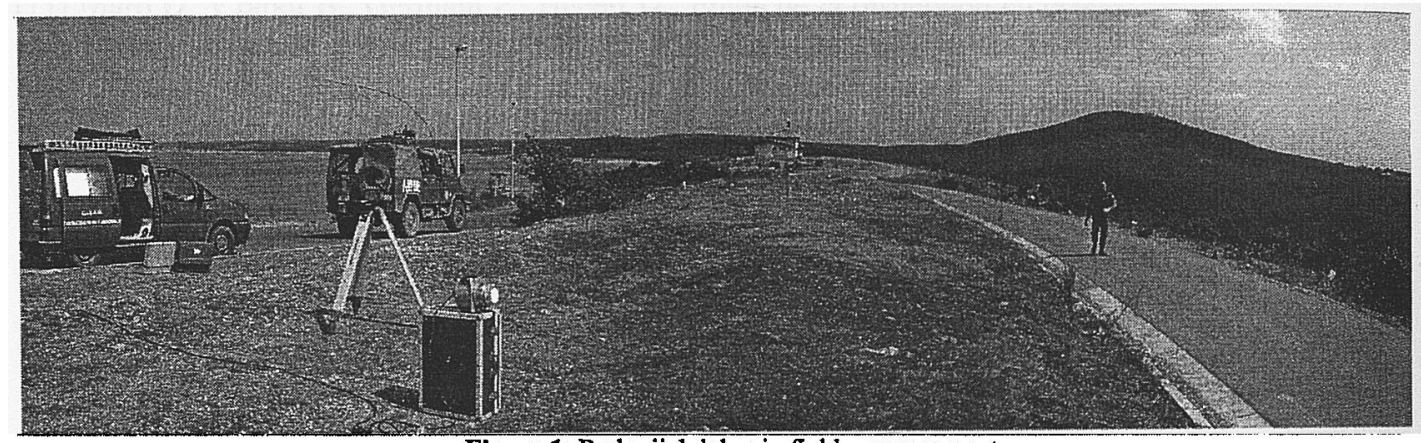

Figure 1: Radonjick lake: in field measurement

The results of the campaigns are summarised below.

\subsection{External exposure}

At $1 \mathrm{~cm}$ from projectile

$$
\begin{aligned}
& \mathrm{Hp}(10)=12 \mathrm{mSv} / \mathrm{h} \\
& \mathrm{Hp}(0,07)=400 \mathrm{mSv} / \mathrm{h}
\end{aligned}
$$

At approximately 1 meter from projectile $» 0,5 \mathrm{mSv} / \mathrm{h}$

\subsection{Contamination of vehicles, tanks houses ecc}

Measurements performed in DU on suspected contaminated objects have not shown excess in the limits of sensitivity. (alfa $=4 \mathrm{mBq} / \mathrm{cm}^{2}$; beta-gamma $=20 \mathrm{mBq} / \mathrm{cm}^{2}$ ).

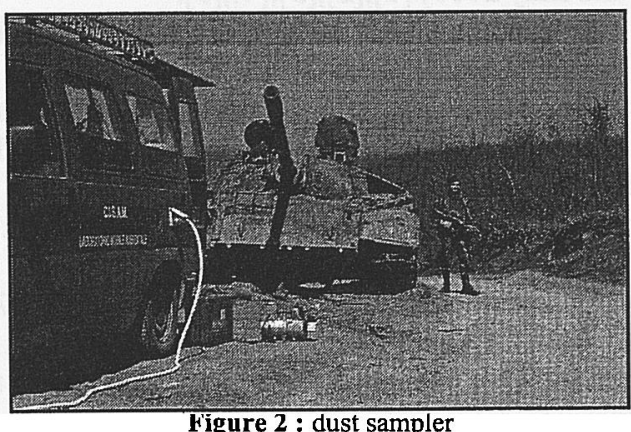

Figure 2 : dust sampler

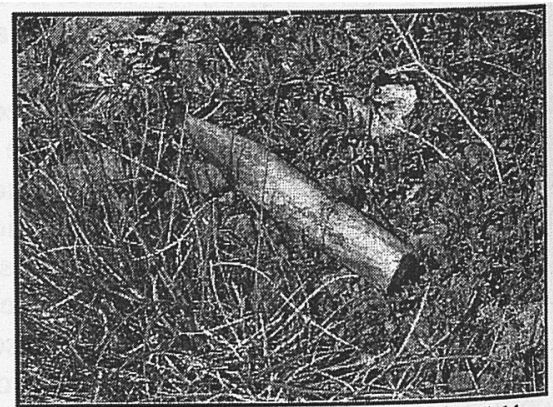

Figure 3 : DU penetrator laying in the field

\subsection{Contamination of ground from "fall out" of airborne DU}

Measurements performed in the area of DU strikes, except near some localised hit points (hot spot) did not show contamination level discernible from the natural uranium present in the soil.

\subsection{Atmospheric particles}

During the sample drawing campaigns of April and August 2000, the measurement data did not exceed the limits of sensitivity: alfa tot. $=0,2 \mathrm{mBq} / \mathrm{m}^{3}$; alfa spectrometry $(\mathrm{E}<5 \mathrm{MeV})=0,1 \mathrm{mBq} / \mathrm{m}^{3}$. 


\subsection{Radiotoxicology}

Urine from soldiers selected among those who have served in risk areas have been tested; to date, none of them has shown to exceed the sensitivity levels set by the adopted methods $(1 \mu \mathrm{g} / \mathrm{l})$.

2.6 Soil

In presence of $\mathrm{U}_{\mathrm{ORE}}(20-40 \mathrm{~Bq} / \mathrm{kg} \mathrm{DRY})$ the limits of sensitivity are estimated to be $5-10 \mathrm{~Bq} / \mathrm{kg} \mathrm{DRY}_{\mathrm{D}}$.

During the sample drawing campaign of August 2000 the level of DU has been found to exceed the $30000 \mathrm{~Bq} / \mathrm{kgDRY}$.

The soil under and around the DU bullets was contaminated. A reasonable justification is that this is an effect of oxidation of DU.

\subsection{Botanical samples (grass, mushrooms, lichens and bark)}

The measurement performed in order to check for the presence of DU as evidence of earlier contamination have not shown excess in the limits of sensitivity estimated to be $5-10 \mathrm{~Bq} / \mathrm{kg}$.

In some sample, the measurements have shown to exceed $20 \mathrm{~Bq} / \mathrm{kg}$.
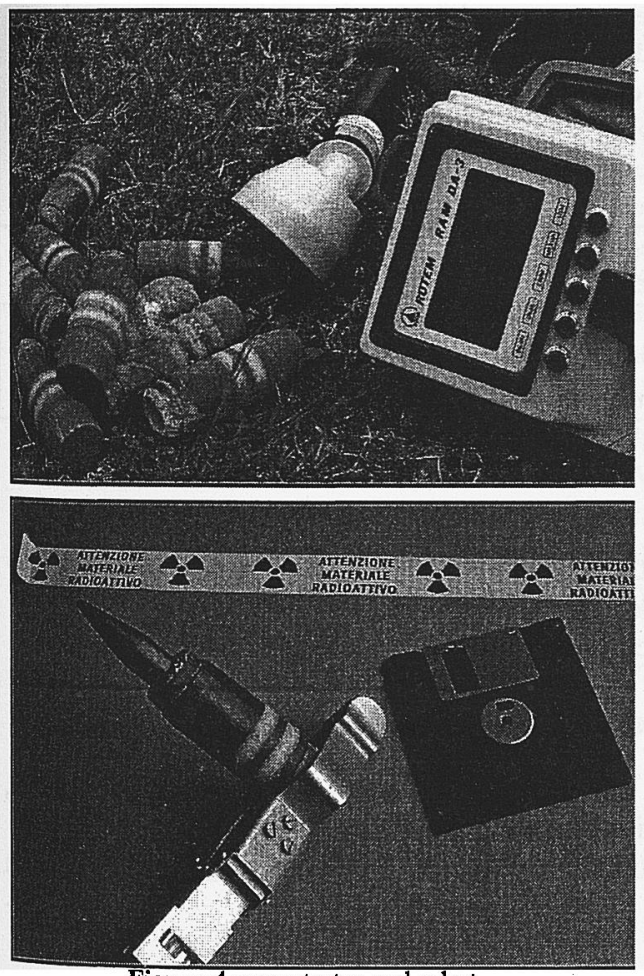

Figure 4 : penetrator and sabot

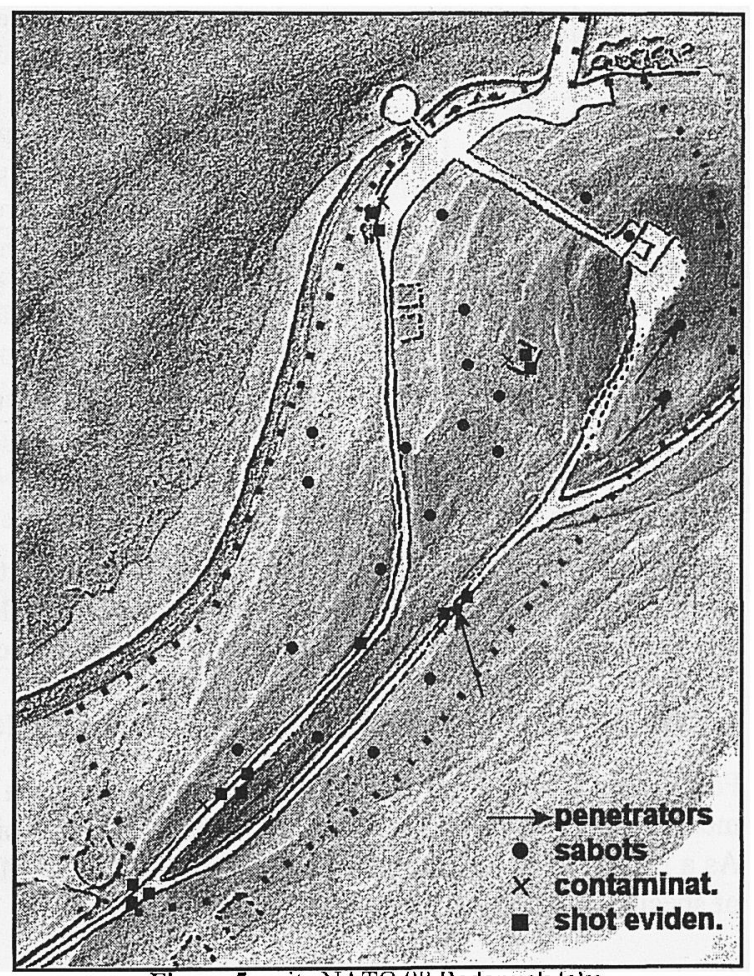

Figure 5 : site NATO 98 Radonjick lake

\section{SUMMARISED DATA ON THE SITE "NATO 98" : RADONJICK LAKE}

\subsection{General information}

The site is located near the large dam on the southern beach of the Radonjick artificial lake at coordinate 32 TDN $532 * * 022 * *$.

According to NATO the area was targeted by 655 shots on 7 June 1999.

The area, investigated by CISAM team in April, August, November 2000 and January 2001 presents clear signs of the use of cluster bombs and anti-tank ammunition including DU. In the vicinity of the roads there were anti-aircraft, infantry and tank positions. 
During the missions NBC specialist removed four DU bullets and about thirty sabots and collected a large number of soil and botanical samples.

CISAM Team performed four gamma field measurements.

\subsection{Hot Spot localised and summarized results}

Eight contaminated holes were found (from 100 to $600 \mathrm{cpm}$ ). There were also two contamination spots in a concrete wall hit by bullets.

In the samples of grass and in the soil there is no evidence of the presence of DU.

In the water samples taken from the lake there is no evidence of DU.

\begin{tabular}{|c|c|c|c|c|c|c|c|}
\hline $\begin{array}{c}\text { Sampling } \\
\text { data }\end{array}$ & $\begin{array}{c}\text { Sample } \\
\text { type }\end{array}$ & Description & \multicolumn{2}{|c|}{$\begin{array}{l}\text { D.U. U. nat } \\
\text { Bq/kg }\end{array}$} & $\begin{array}{l}\mathrm{U} 235 \\
\mathrm{~Bq} / \mathrm{kg}\end{array}$ & $\begin{array}{c}\mathrm{K} 40 \\
\mathrm{~Bq} / \mathrm{kg}\end{array}$ & $\begin{array}{l}\mathrm{Cs}-137 \\
\mathrm{~Bq} / \mathrm{kg}\end{array}$ \\
\hline \multirow{3}{*}{ October '99 } & Soil & depth: $0-5 \mathrm{~cm}$ at $1 \mathrm{~m}$ from a hot-spot & 136 & 26 & n.r. & n.r. & n.r. \\
\hline & Soil & depth: $0-5 \mathrm{~cm}$ at $1 \mathrm{~m}$ from a hot-spot & 158 & 16 & n.r. & n.r. & n.r. \\
\hline & Soil & depth: $0-5 \mathrm{~cm}$ at $1 \mathrm{~m}$ from a hot-spot & 438 & 23 & n.r. & n.r. & n.r. \\
\hline \multirow{6}{*}{ April '00 } & Soil & depth : $0-3 \mathrm{~cm}$ in clean area & $<17$ & $<15$ & n.r. & n.r. & 119 \\
\hline & Soil & depth: $0-3 \mathrm{~cm}$ near a shot evidence & 5 & $<2$ & n.r. & n.r. & 26 \\
\hline & Soil & depth: $0-3 \mathrm{~cm}$ at $3 \mathrm{~m}$ from a shot evidence & $<4$ & $<3$ & n.r. & n.r. & 26 \\
\hline & Bio & lichen: Usnea near a hot-spot & $<57$ & $<57$ & n.r. & n.r. & 666 \\
\hline & Bio & fungus: Lycoperdon near a shot evidence & 20 & $<5$ & n.r. & n.r. & 12 \\
\hline & Soil & depth: $0-3 \mathrm{~cm}$ near Lycoperdon & 8 & $<5$ & n.r. & n.r. & 33 \\
\hline \multirow{2}{*}{ August '00 } & Soil & depth: $0-5 \mathrm{~cm}$ near the road and a shot evidence & $<10$ & 33 & n.r. & n.r. & n.r. \\
\hline & Soil+bio & soil + moss, depth: $0-5 \mathrm{~cm}$ near the road & $<10$ & 30 & n.r. & n.r. & n.r. \\
\hline \multirow{3}{*}{ November 00} & Soil & soil on a hot-spot & 10600 & 75 & 150 & 615 & 40 \\
\hline & Soil & soil near the house & $<10$ & 10 & $<0,4$ & 134 & 16 \\
\hline & Soil & soil southern beach near the dam & $<10$ & 15 & 0,5 & 137 & 8 \\
\hline
\end{tabular}

\subsection{Local risk}

There is no risk of exposition at high radiation dose for the military personnel; nevertheless it is necessary to inform people about the possible presence of DU bullets in the area.

DU Bullets and sabots should not be kept at home, and children should be warned not to touch them.

\section{COMMISSION OF THE MINISTER OF DEFENCE - CHAIRMAN FRANCO MANDELLI}

Following claims of an supposed excess of leukaemia amongst Italian troops deployed in the Balkans, media reports postulated a link with the use do DU munitions during the Balkans conflict.

As a results of these interest on January 2001 Italian Minister of Defence announced the implementation of special commission to study the problems.[6]

The last conclusion of this commission are:

......'The significantly lower number of cases of cancer could be due in part to military personnel being healthier than the general population (the well known healthy worker effect) and in part due to geographic differences in the incidence of cancer and in the area of origin of military personnel.

The excess of cases of Hodgkin lymphoma (statistically significant) and of acute lymphatic leukaemia (not significant), should be further investigated among the Italian as well as the entire cohort of European troops sent to the Balkans.

Since a casual relationship between external exposure to uranium and lymphomas has never been demonstrated, also others factors should be considered.

Further studies could be extremely valuable for assessing the true role of uranium, if any, in addition to the role of exposure to other factor." 


\section{CONCLUSIONS}

- The activity of Italian NBC companies was very intensive and the BMNW's maps are dotted with numerous "NBC reconnaissance with ......".

- Experience obtained in the field, suggested that the problem from depleted uranium in Kosovo are less than the ones from general pollution, nevertheless the radioactivity is still measurable on area covered with concrete or on tarmac road.

- The CISAM Team continue to monitor the sites where DU was used to check, f.i., the radioactivity of water used for drinking.

- The careful research in areas affected by DU munitions shows the level of radiation is meaningful only near the "hot spot".

- The World Health Organization (WHO),[7] the United Nation Environment Programme (UNEP) [8] also carried out a research on Kosovo and presents comparable results to CISAM Team ones.

\section{References}

1. V. Sabbatini, Indagine ambientale sull 'impiego del DU nell'area del contingente italiano in Kosovo. IX Seminario NBC, Rieti, Maggio 2000.

2. A.Benedetti, Misure e valutazioni radioprotezionistiche relative all'utilizzo bellico del DU in Kosovo, LXXXVI Congresso SIF, Palermo, Ottobre 2000.

3. A. Benedetti, A.Boccolini, G.Gremigni e V.Sabbatini, Valutazioni radioprotezionistiche relative all'utilizzo bellico del DU in Kosovo, X Convegno SIRR, Frascati, Novembre 2000.

4. V. Sabbatini; Controlli e valutazioni di radioprotezione nelle aree dei contingenti italiani in Bosnia e Kosovo, Centro Studi e Ricerche di Sanità e Veterinaria, Workshop su "Uranio Depleto e marcatori di predisposizione alle radiazioni ionizzanti", Scuola Tramat, Roma, 1 Giugno 2001

5. A. Benedetti: Radioprotection evaluation relative to the use of $D U$ in Kosovo, $48^{\text {th }}$ Annual Meeting of the Health Physics Society, Cleveland giugno 2001.;

6. Commission of the Minister of Defence: F.Mandelli; C.Biagini; M.Grandolfo; A.Mele; G.Onufrio, V.Sabbatini e A.Tricarico Cancer incidence among Italian peace-keeping forces employed in the Balkans, . In corso di pubblicazione su British Journal of Medicine, Maggio 2001

7. WHO 2001, B.Smith, Y.Hayashi and a. Ferguson, Depleted Uranium sources, exposure and health effects Draft 7/1/2001.

8. UNEP, Depleted Uranium in Kosovo - Post conflict environmental assessment march 2001. 